\title{
Analysis of the Main Factors Affecting the Adoption of Cloud based Interactive Mobile Learning in the Australian Higher Education Sector
}

\author{
https://doi.org/10.3991/ijim.v12i4.9200 \\ Nitirajsingh Sandu( $\left.{ }^{(}\right)$ \\ KENT Institute, Sydney, Australia \\ raj.sandu@kent.edu. au \\ Ergun Gide \\ Central Queensland University, Sydney, Australia
}

\begin{abstract}
Today, every business depends on Information Technology (IT) for the efficient service delivery and cost-effective application of technological resources. Modern technologies are being adopted to overcome business pressure, streamline existing procedures and service delivery cost-efficiency for maximising profit due to the increase in global competition and shifts in the customer expectations. Cloud computing (CC) is an Internet-centric computing service that utilises and provides IT services to organisations through the provisioning of resources through the Internet using web-centric software and gadgets without the assistance of any private IT architecture within the firm. Cloud based interactive mobile learning platform is the result of such exploration and this practice of learning is improving with the time. New technologies such as smart mobile devices, Cloud computing and wireless connectivity are opening new opportunities of learning for students.

Thus, the aim of this paper is to evaluate the main factors affecting the adoption of Cloud based interactive mobile learning for the Australian Higher Education sector. In this research, a survey data collection technique with existing students using Mobile application for learning and also a literature review process were conducted. Research outcome shows that the use of Artificial intelligence and Machine learning can make learning more efficient and these technologies need to be integrated in applications designed for Australian Higher Education sector. It is expected that the research outcome will help interactive mobile application developers and higher education providers to better understand the requirements of students while providing an interactive learning platform for them.
\end{abstract}

Keywords - Cloud computing (CC), Mobile application, Artificial Intelligence (AI), Machine Learning (ML), Mobile learning, Australian Higher Education sector 


\section{Introduction}

In an organisation, the adoption of modern technologies needs to be fulfilled in a planned manner so that the internal and external pressure can be minimized. Cloud computing (CC) is an Internet-centric computing service that utilises and provides IT services to organisations through the provisioning of resources through the Internet using web-centric software and gadgets without the assistance of any private IT architecture within the firm [1]. Cloud based interactive mobile learning platform is the result of such exploration and this practice of learning is improving with time. New technologies such as smart mobile devices, CC and wireless connectivity are opening new opportunities of learning for higher education students [2, 24, 28]. Therefore, the main aim of the research was to make an evaluation of the main factors that affect the adoption of Cloud based interactive mobile learning platform for Australian Higher Education sector.

The data was collected through the use of survey of the existing higher education students using interactive mobile applications for learning and teaching as well as literature review techniques. The data was analysed through the use of the SPSS, and comparative analysis has been performed through graphs. The preliminary results that were obtained clearly show that the use of Artificial intelligence and Machine learning can make learning more efficient and effective and these technologies need to be integrated into applications designed for Australian higher education sector.

Therefore, the main objective of this research was to evaluate main factors affecting the adoption of Cloud based interactive mobile learning platform for Australian Higher Education sector.

\section{Literature review}

The use of Cloud based system for learning is still an emerging issue when it comes to sharing of learning resources on the Internet anywhere and anytime [3]. The technology has been proven to be beneficial to the higher education system especially in Australia as it helps in the offering of flexible services on demand [4]. The resources can be accessible at any time and any place and it enhances teaching and learning in the higher education sector [5]. This new method of learning has been accepted by few people in the education sector although there has been better acceptance in sectors such as business organizations and individual people. Learning through the use of mobile devices is however limited in the processing power, the storage capacity, the hardware and some software limitations, although it has significant benefits when it comes to educational communication and enhancement of the pedagogical framework $[2,26]$.

Despite the growing popularity and increased emergence of the Cloud-based learning systems, there are several studies that point towards a certain degree of limitation in the user levels [6]. The researchers have argued that the biggest challenge facing the Cloud-based adoption is not in the technology used but the attitude and perception that people have attached to the technology [7]. The study of the experiences of the 
users have shaped the learning context on a Cloud based way and the critical factors that mainly have an influence on the use of the technology has also been studied in detail [8]. From what emerges from the past study that has been done on the same topic, the main factors include the intention of the users and the satisfaction that is derived when using the technology in learning [9].

The use of mobile technology combined with Cloud computing has several benefits to learners that are significant and open but it is worth having a clear understanding that it may not be the main factor that may guarantee the wide scale adoption and use of the technology by the users [10]. The whole process of accepting the technology and its usage depends largely on the desire of the user to accept it as part of something that is beneficial. The stakeholders therefore need to study and understand the desires of the users and how they can influence them to avoid the risks that come up after implementation.

There are some benefits that are associated with Cloud computing that need an understanding [11]. The traditional forms of mobile learning have some costs such as network costs, low rates of transmission of data and a limited availability of resources [23]. Therefore, the disadvantages of the traditional learning methods are made to be solved by Cloud computing [11]. The benefits are both on the side of the providers of the service and the learners. It saves the initial costs of the providers and spending on the hardware and software that is incurred during the installation stage[12]. The small schools and universities could gain instant benefits by provision of the Cloud learning services without the need to incur the unaffordable high setup costs. There is also no need to upgrade their hardware and software components since all the upgrade and related activities are done on the administrator side and therefore the use of the mobile devices is only for display [13]. Other benefits of the Cloud computing process are that there is no need to update the mobile phone software for which it has limited or no space to accommodate, and thus it is a very efficient method of learning. The smart mobile phones and other handheld devices are able to view the data and learning materials without the need for installing, purchasing or updating any new software.

Cloud computing can be accessed as long as there is availability of network and the Internet connection on the mobile devices $[11,27]$. This therefore implies that the students who live in rural and less developed areas could have access to the learning materials through $3 \mathrm{G}$ connections or any other ways [14]. They could also include the use of a Cloud data centre for learning of some selected topics and this is also one of the major advantages of Cloud computing. The program also does not require personal subscription as some institutions may subscribe to the institution packages that may be beneficial to the organization and this is especially helpful to those that need heavy usage of the service [15]. The fact that it could be accessed from any part of the world makes it efficient for usage of the students in instances where they are far from the school or learning institution.

There is an availability of more educational resources in the Cloud computing since these are services available for usage by different institutions, schools and universities [16]. This also improves the collaboration of students from different learning 
areas and it is the biggest advantage that is attached to mobile Cloud computing, especially in higher education in Australia.

Further, over the last two decades, Machine learning (ML) has progressed dramatically from laboratory experiments to practical application of technology for commercial use. Machine learning had emerged as a promising field within artificial intelligence (AI) [25]. ML has emerged as the method of choice for developing practical software for robotics, computer vision, Natural Language Processing (NLP), speech recognition, and other applications [17].

Machine learning addresses the question of how to build information systems that improve automatically through experience. According to Owens [18], ML is an automating application that works by developing a program which learns how to process new information by using past examples. As training time in traditional settings is costly due to scarce resources across education operations, ML provides the benefit of improving training, as well as the added benefit of data analytics and ultimately reducing the cost of training [19].

This research shows that there is a limited understanding of the major and critical factors that affect the adoption of mobile technology process. This study therefore takes a look at the major organizations that are aware of the benefits of the mobile technology but do not clearly understand the main factors that may have caused the users of the model to accept or reject the new technology.

\section{$3 \quad$ Research Methods}

\subsection{Setting and participants}

The success factor for the implementation of the Cloud based learning in Australia highly depends on the related factors since this is a service that is delivered in different forms and models for the learning institution. The factors are unclear and they call for the inclusion of a clear and well investigated method of determining the main reasons as to why it is not being adopted on a wide scale. Two research questions were framed for this research:

RQ1-Does Interactive Mobile application improve the learning and teaching experience among higher education students?

RQ2 - Can Artificial Intelligence and Machine learning make student learning more efficient and effective?

To determine the factors, this research conducted a survey of existing higher education students using interactive mobile applications for learning and teaching. Comprehensive literature review techniques have also been used. The study therefore was conducted through the distribution of questionnaires and it was sent to students studying in a higher education institution to collect the data. The selection of the respondents was done randomly to ensure that there is credibility in the whole process of collection and analysis, and those that were willing to take part in the study were considered. The survey was sent to 530 students through email, with 51 responses received. Some of the respondents did not complete some sections of the survey and 
were excluded from the analysis. Therefore in total, 37 completed surveys were deemed suitable for data analysis. The survey had a usable completed rate of return of approximately $7 \%$.

\section{$4 \quad$ Results of data analysis}

This section gives a brief report of the results of data analysis and seeks to provide answers to the research questions in consideration. Data analysis started by checking the reliability of the scale used to measure experience using Mobile Learning. The below sections show the results of data analysis accordingly.

\subsection{Reliability test}

Cronbach's alpha test was used to assess the reliability of the scale which was used to measure experience using Mobile Learning; a reported Cronbach's alpha $(\alpha)$ value was .889 with a standardized item of .908 . As shown in Table 1 , these reported values indicate that the scale is sufficiently reliable.

Table 1. Cronbach's alpha test

\begin{tabular}{|c|c|c|}
\hline Cronbach's Alpha & $\begin{array}{c}\text { Cronbach's Alpha Based on } \\
\text { Standardized Items }\end{array}$ & N of Items \\
\hline .889 & .908 & 17 \\
\hline
\end{tabular}

\subsection{Demographic information of participants}

The results that were obtained are adequate considering the nature of the study. The distribution of gender was not a relevant issue in the study, although there was need to consider both males and females in the collection of data. The data that was obtained also showed that the younger generation was mostly considered since the technology of Cloud computing is a new technology that could be effectively implemented by the younger generation [15]. However, there was inclusion of the older generation during the collection process as there was need to collect robust data that gives an all-round representation. The gender distribution of the respondents showed that 23 respondents, corresponding to $62.2 \%$, were males while $14(37.8 \%)$ respondents were females. So, it can be concluded that both genders are well represented in the study as shown in Table 2 .

The age distribution of respondents featured in the study reported the majority $(59.5 \%)$ were between the ages of $18-24$ years, $35 \%$ were $25-34$ years, while the least $(5.5 \%)$ were $35-44$ years. The right skewed nature of the age distribution shows that a greater proportion of younger participants engaged in the study, which supports the assumption that Mobile Learning is a way forward for the millennia. A majority of the respondents gave the Moodle app a four-star rating and this therefore shows that the general usability of the application is not the main problem that may be hindering adaptability of the technology as shown in Figure 1. This therefore called for the need 
to go to certain key aspects of the application and the questions began by first asking about the issues that were experienced during the use of the application.

Ratings of the Moodle mobile app were 4 stars (38\%) as majority, followed by 5 stars (32.5\%). $27 \%$ gave 3 -star ratings, while only $2.5 \%$ gave a 1 -star rating. Average ratings were $3.97(\mathrm{SD}=.915)$. Noteworthy is the fact that there was no 2-star rating.

Table 2. Descriptive summary of Demography and application rating

\begin{tabular}{|c|c|c|c|}
\hline Question & Response & Frequency & Percent \\
\hline \multirow{2}{*}{ Gender } & Male & 23 & 62.2 \\
\hline & Female & 14 & 37.8 \\
\hline \multirow{3}{*}{$\begin{array}{l}\text { Which category below includes your } \\
\text { age? }\end{array}$} & $18-24$ & 22 & 59.5 \\
\hline & $25-34$ & 13 & 35.0 \\
\hline & $35-44$ & 1 & 5.5 \\
\hline \multirow{6}{*}{$\begin{array}{l}\text { How would you rate the Moodle } \\
\text { mobile app? }\end{array}$} & 1 & 1 & 2.5 \\
\hline & 3 & 10 & 27.0 \\
\hline & 4 & 14 & 38.0 \\
\hline & 5 & 12 & 32.5 \\
\hline & Mean & 3.97 & \\
\hline & Standard Dev. & .915 & \\
\hline
\end{tabular}

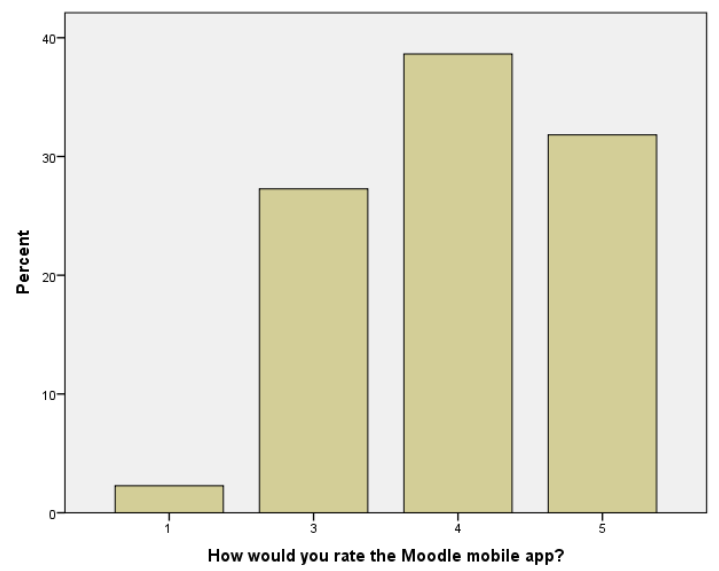

Fig. 1. Rating of Moodle mobile app

\subsection{Experience using interactive Moodle mobile application}

When it comes to what respondents like most about Moodle, the majority (27\%) liked its functionality over every other feature, followed by content $(27 \%)$, navigation (19\%), stability (16.2\%), speed (5.4\%), look and feel $(2.7 \%)$, while $2.7 \%$ liked other features not stated here, such as easy access to documents from lecturers as shown in Table 3. 
Table 3. Experience by student using Moodle application

\begin{tabular}{|c|c|c|c|}
\hline Question & Response & Frequency & Percent \\
\hline \multirow{6}{*}{$\begin{array}{l}\text { Which of the issues } \\
\text { below was the biggest } \\
\text { problem during your } \\
\text { experience with Moodle? }\end{array}$} & I experienced bugs & 1 & 2.7 \\
\hline & The app was missing features I needed & 9 & 24.2 \\
\hline & The app was confusing to use & 10 & 27 \\
\hline & The app was visually unappealing & 7 & 19 \\
\hline & The app crashed & 1 & 2.7 \\
\hline & Other & 9 & 24.4 \\
\hline \multirow{7}{*}{$\begin{array}{l}\text { What do you like most } \\
\text { about Moodle? }\end{array}$} & Navigation & 7 & 19 \\
\hline & Functionality & 10 & 27 \\
\hline & Look and feel & 1 & 2.7 \\
\hline & Speed & 2 & 5.4 \\
\hline & Stability & 6 & 16.2 \\
\hline & Content & 10 & 27 \\
\hline & Other & 1 & 2.7 \\
\hline \multirow{7}{*}{$\begin{array}{l}\text { What do you like least } \\
\text { about Moodle? }\end{array}$} & Navigation & 15 & 40.5 \\
\hline & Functionality & 6 & 16.2 \\
\hline & Look and feel & 4 & 10.8 \\
\hline & Speed & 7 & 19 \\
\hline & Stability & 2 & 5.4 \\
\hline & Content & 1 & 2.7 \\
\hline & Other & 2 & 5.4 \\
\hline \multirow{4}{*}{$\begin{array}{l}\text { How easy is it to find the } \\
\text { information you are } \\
\text { looking for in Moodle } \\
\text { mobile apps? }\end{array}$} & Extremely easy & 7 & 19 \\
\hline & Very easy & 14 & 37.8 \\
\hline & Moderately easy & 10 & 27 \\
\hline & Slightly easy & 6 & 16.2 \\
\hline
\end{tabular}

The navigation was the least liked features about Moodle (40.5\%), followed by speed $(19 \%)$ as it was claimed to be slow by some, functionality $(16.2 \%)$ - perhaps Moodle is not as functional as was expected in terms of flexibility, followed by the look and feel $(10.8 \%)$, stability $(5.4 \%)$, and content $(2.7 \%)$, while 2 respondents chose other features not stated here - they responded good to all the features i.e. they liked all the features.

The majority $(27 \%)$ of the respondents responded that their biggest issues during their experience with Moodle was that the app was confusing to use. $24.2 \%$ also noted that it was missing features they needed, $19 \%$ said the app was visually unappealing, $2.7 \%$ experienced bugs, $2.7 \%$ reported the app crashed, and $24.4 \%$ responded with other problems not captured in the options listed here such as: Not easy to navigate, it logs them out every 15 minutes, can't really see comments by teacher after they have reviewed the assignments, slow, being unable to see results for one course after changing from the course to another course, opening several tabs when opening a link, and being unable to see a complete assignment after submitting it.

The majority of the respondents felt that the app was confusing to use and missing some features which draws to the need to increase the efficiency of usage if the tech- 
nology is to be adopted by higher education students[20]. The functionality of the application was the concept that was liked most and the speed liked least by the respondents. This also draws to the need to increase the efficiency during usage of the application in terms of speed. The navigation of the app was another concept that was liked least by the respondents, highlighting the need to improve in that area. The ease of finding information that is being searched for in the application appears to be easy, according to data obtained during the study, although there is still the need to improve it as there are those that still felt the app was complex in terms of finding information, as shown in Figure 2.

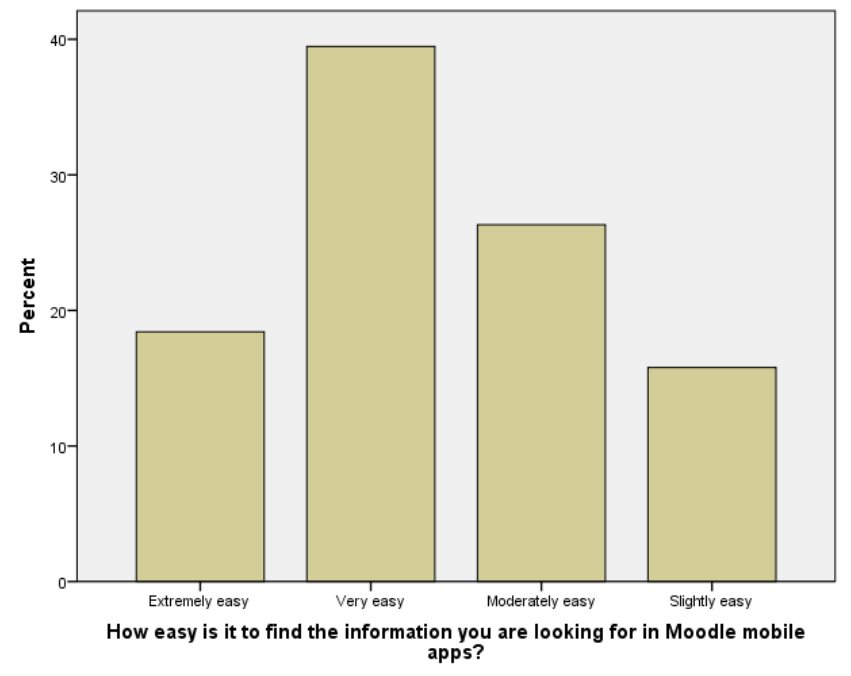

Fig. 2. Ease of finding information on Moodle as perceived by students

Overall, it can be concluded that finding needed information on Moodle by the users isn't difficult as the majority (56.8\%) finds it as least very easy, $27 \%$ find it moderately easy, and $16.2 \%$ find it slightly easy, while none finds it difficult. The majority of the respondents agreed that the app was easy to use and could navigate it easily and without the need for written instructions. The language that was used in the app was also said to be easy to use and understand and the app was cohesive from the general agreement that was obtained from the study [21]. In terms of documentation, the respondents felt that the app has the necessary documentation and this therefore was not among the main promoting factors for the low adoption of the technology. There is, however, an increasing importance of drawing to those factors that have a general agreement but with a low vote, since they are also important in making decisions regarding the app and its usage.

Going by students' responses to their experience using mobile learning, the majority $(97.3 \%)$ of them agreed that they found the app easy to use, while $2.7 \%$ disagreed, as displayed in Table 4. This leaves us with the conclusion that considerably, users don't have difficulties when it comes to the use of the app. Since the majority found 
the app easy to use, we can expect the majority of users as well, to be able to use the app without written instructions. The outcome wasn't far from the expected response, as $89.2 \%$ agreed that they can use the app without written instruction, while $10.8 \%$ disagreed. The use of the app involves navigation and accessing other features. $89.2 \%$ of the respondents agreed that they can navigate through the app easily, while only $10.8 \%$ disagreed. We can therefore conclude that navigation isn't so much of a challenge for the user of the app.

Table 4. Students experience using mobile learning

\begin{tabular}{|c|c|c|c|c|c|c|c|}
\hline $\begin{array}{l}\text { Ques- } \\
\text { tion }\end{array}$ & Response & $\begin{array}{c}\text { Fre- } \\
\text { quency }\end{array}$ & $\begin{array}{l}\text { Per- } \\
\text { cent }\end{array}$ & Question & Response & $\begin{array}{c}\text { Fre- } \\
\text { quency }\end{array}$ & $\begin{array}{l}\text { Per- } \\
\text { cent }\end{array}$ \\
\hline \multirow{7}{*}{ 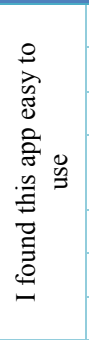 } & Strongly agree & 5 & 13.5 & \multirow{8}{*}{ 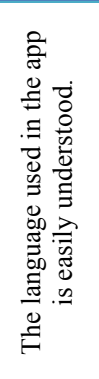 } & Strongly agree & 9 & 24.4 \\
\hline & Agree & 23 & 62.3 & & Agree & 19 & 51.3 \\
\hline & Somewhat Agree & 8 & 21.5 & & Somewhat Agree & 6 & 16.2 \\
\hline & $\begin{array}{l}\text { Neither Agree nor Disa- } \\
\text { gree }\end{array}$ & 1 & 2.7 & & Neither Agree nor Disagree & 2 & 5.4 \\
\hline & Total Agree & 36 & 97.3 & & Strongly Disagree & 1 & 2.7 \\
\hline & Total Disagree & 1 & 2.7 & & Total Agree & 34 & 91.9 \\
\hline & & & & & Total Disagree & 3 & 8.1 \\
\hline \multirow{7}{*}{ 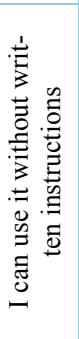 } & Strongly agree & 7 & 19 & & & & \\
\hline & Agree & 19 & 51.3 & \multirow{7}{*}{ 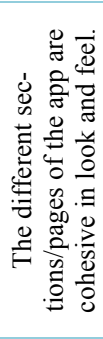 } & Strongly agree & 6 & 16.2 \\
\hline & Somewhat Agree & 7 & 19 & & Agree & 19 & 51.3 \\
\hline & $\begin{array}{c}\text { Neither Agree nor Disa- } \\
\text { gree }\end{array}$ & 3 & 8 & & Somewhat Agree & 9 & 21.7 \\
\hline & Somewhat Disagree & 1 & 2.7 & & Neither Agree nor Disagree & 3 & 8.1 \\
\hline & Total Agree & 33 & 89.2 & & Disagree & 1 & 2.7 \\
\hline & Total Disagree & 4 & 10.8 & & Total Agree & 33 & 89.2 \\
\hline \multirow{7}{*}{ 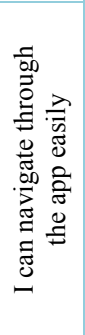 } & Strongly agree & 6 & 16.2 & & Total Disagree & 4 & 10.8 \\
\hline & Agree & 19 & 51.3 & \multirow{6}{*}{ 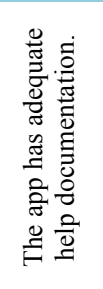 } & Strongly agree & 7 & 19 \\
\hline & Somewhat Agree & 8 & 21.7 & & Agree & 21 & 56.7 \\
\hline & $\begin{array}{l}\text { Neither Agree nor Disa- } \\
\text { gree }\end{array}$ & 2 & 5.4 & & Somewhat Agree & 4 & 10.8 \\
\hline & Somewhat Disagree & 2 & 5.4 & & Neither Agree nor Disagree & 5 & 13.9 \\
\hline & Total Agree & 33 & 89.2 & & Total Agree & 32 & 86.5 \\
\hline & Total Disagree & 4 & 10.8 & & Total Disagree & 5 & 13.5 \\
\hline
\end{tabular}

Language used in the app was found not to be a hindrance to its users, as $91.9 \%$ of the respondents agreed that the language used in the app is easily understood. This is also expected to correlate with the ease of use and navigation of the app. It was believed and agreed by the majority $(89.2 \%)$ of the respondents, that the different sections/pages of the app are cohesive in look and feel, while $10.8 \%$ disagreed. The app was believed to have adequate help documentation by the majority $(86.5 \%)$ of the respondents, while $13.5 \%$ believes the help documentation can still be improved. 
Table 4. Students experience using mobile learning (cont'd)

\begin{tabular}{|c|c|c|c|c|c|c|c|}
\hline Question & Response & $\begin{array}{l}\text { Fre- } \\
\text { quency }\end{array}$ & $\begin{array}{l}\text { Per- } \\
\text { cent }\end{array}$ & $\begin{array}{l}\text { Ques- } \\
\text { tion }\end{array}$ & Response & $\begin{array}{l}\text { Fre- } \\
\text { quency }\end{array}$ & $\begin{array}{l}\text { Per- } \\
\text { cent }\end{array}$ \\
\hline \multirow{8}{*}{ 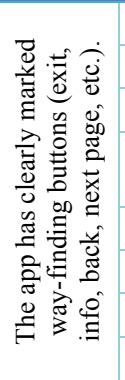 } & Strongly agree & 3 & 8.1 & \multirow{8}{*}{ 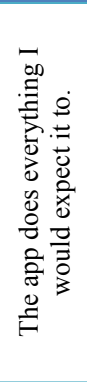 } & Strongly agree & 5 & 13.5 \\
\hline & Agree & 17 & 45.9 & & Agree & 17 & 45.9 \\
\hline & Somewhat Agree & 12 & 32.4 & & Somewhat Agree & 10 & 27.0 \\
\hline & $\begin{array}{c}\text { Neither Agree nor Disa- } \\
\text { gree }\end{array}$ & 2 & 5.4 & & Neither Agree nor Disagree & 3 & 8.1 \\
\hline & Somewhat Disagree & 1 & 2.7 & & Somewhat Disagree & 1 & 2.7 \\
\hline & Disagree & 2 & 5.4 & & Disagree & 1 & 2.7 \\
\hline & Total Agree & 32 & 86.5 & & Total Agree & 32 & 86.5 \\
\hline & Total Disagree & 5 & 13.5 & & Total Disagree & 5 & 13.5 \\
\hline \multirow{7}{*}{ 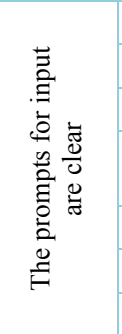 } & Strongly agree & 6 & 16.7 & \multirow{8}{*}{ 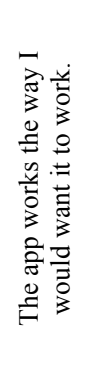 } & Strongly agree & 3 & 8.1 \\
\hline & Agree & 19 & 51.3 & & Agree & 21 & 56.8 \\
\hline & Somewhat Agree & 8 & 21.2 & & Somewhat Agree & 10 & 27.0 \\
\hline & $\begin{array}{l}\text { Neither Agree nor Disa- } \\
\text { gree }\end{array}$ & 4 & 10.8 & & Neither Agree nor Disagree & 2 & 5.4 \\
\hline & Total Agree & 33 & 89.2 & & Somewhat Disagree & 1 & 2.7 \\
\hline & Total Disagree & 4 & 10.8 & & Total Agree & 34 & 91.9 \\
\hline & & & & & Total Disagree & 3 & 8.1 \\
\hline \multirow{9}{*}{ 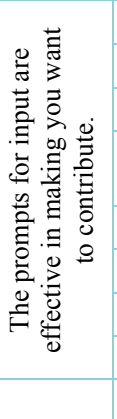 } & Strongly agree & 7 & 19 & & & & \\
\hline & Agree & 15 & 40.5 & \multirow{8}{*}{ 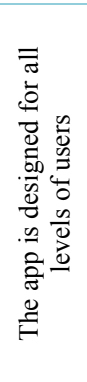 } & Strongly agree & 4 & 10.8 \\
\hline & Somewhat Agree & 13 & 35.1 & & Agree & 22 & 59.1 \\
\hline & $\begin{array}{l}\text { Neither Agree nor Disa- } \\
\text { gree }\end{array}$ & 1 & 2.7 & & Somewhat Agree & 5 & 13.9 \\
\hline & Disagree & 1 & 2.7 & & Neither Agree nor Disagree & 3 & 8.1 \\
\hline & Total Agree & 35 & 94.6 & & Somewhat Disagree & 2 & 5.4 \\
\hline & Total Disagree & 2 & 5.4 & & Strongly Disagree & 1 & 2.7 \\
\hline & & & & & Total Agree & 31 & 83.8 \\
\hline & & & & & Total Disagree & 6 & 16.2 \\
\hline
\end{tabular}

There are other areas that were investigated by the research that are worth mentioning about the Moodle application. The app was found to have clearly marked wayfinding buttons, clear prompts for input, prompts for input are effective in making you want to contribute, works the way I would want it to work, and is designed for all levels of users, although some of the respondents felt that it was unnecessarily complex. The app was largely agreed to have clearly marked way-finding buttons such as exit, info, back, next page etc. by $86.5 \%$ of respondents, while $13.5 \%$ disagreed with this claim. It can be concluded that the app is perceived by the majority to have clearly marked way-finding buttons such as exit, info, back, next page etc. The prompts for input are agreed by the majority $(94.6 \%)$ to be clear enough. They are also agreed by $94.6 \%$ of respondents to be effective in making users want to contribute. The majority $(86.5 \%)$ of the respondents agreed that the app does everything they would expect it to do and $91.9 \%$ also agreed it works the way they would want it to work. The app is also agreed by the majority $(83.8 \%)$ to be designed for all levels of users. 
Table 4. Students experience using mobile learning (cont'd)

\begin{tabular}{|c|c|c|c|c|c|c|c|}
\hline $\begin{array}{l}\text { Ques- } \\
\text { tion }\end{array}$ & Response & $\begin{array}{c}\text { Fre- } \\
\text { quency }\end{array}$ & $\begin{array}{l}\text { Per- } \\
\text { cent }\end{array}$ & $\begin{array}{l}\text { Ques- } \\
\text { tion }\end{array}$ & Response & $\begin{array}{c}\text { Fre- } \\
\text { quency }\end{array}$ & $\begin{array}{l}\text { Per- } \\
\text { cent }\end{array}$ \\
\hline \multirow{7}{*}{ 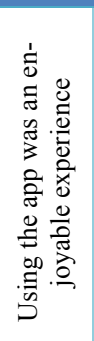 } & Strongly agree & 6 & 16.2 & \multirow{7}{*}{ 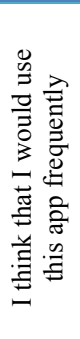 } & Strongly agree & 7 & 18.9 \\
\hline & Agree & 17 & 45.9 & & Agree & 19 & 51.4 \\
\hline & Somewhat Agree & 8 & 21.6 & & Somewhat Agree & 8 & 21.6 \\
\hline & $\begin{array}{l}\text { Neither Agree nor Disa- } \\
\text { gree }\end{array}$ & 4 & 10.8 & & Neither Agree nor Disagree & 2 & 5.4 \\
\hline & Somewhat Disagree & 2 & 5.4 & & Somewhat Disagree & 1 & 2.7 \\
\hline & Total Agree & 31 & 83.8 & & Total Agree & 34 & 91.9 \\
\hline & Total Disagree & 6 & 16.2 & & Total Disagree & 3 & 8.1 \\
\hline \multirow{9}{*}{ 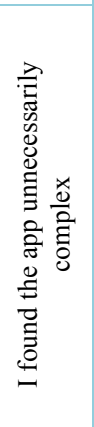 } & Strongly agree & 1 & 2.7 & \multirow{8}{*}{ 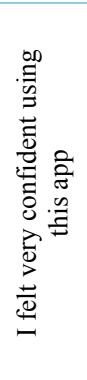 } & Strongly agree & 5 & 13.5 \\
\hline & Agree & 6 & 16.2 & & Agree & 22 & 59.5 \\
\hline & Somewhat Agree & 6 & 16.2 & & Somewhat Agree & 8 & 21.6 \\
\hline & $\begin{array}{l}\text { Neither Agree nor Disa- } \\
\text { gree }\end{array}$ & 4 & 10.8 & & Somewhat Disagree & 2 & 5.4 \\
\hline & Somewhat Disagree & 7 & 18.9 & & Total Agree & 35 & 94.6 \\
\hline & Disagree & 11 & 29.7 & & Total Disagree & 2 & 5.4 \\
\hline & Strongly Disagree & 2 & 5.4 & & & & \\
\hline & Total Agree & 13 & 35.1 & & & & \\
\hline & Total Disagree & 24 & 64.9 & & & & \\
\hline \multirow{7}{*}{ 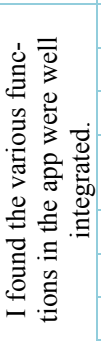 } & Strongly agree & 4 & 10.8 & & & & \\
\hline & Agree & 26 & 70.3 & & & & \\
\hline & Somewhat Agree & 3 & 8.1 & & & & \\
\hline & $\begin{array}{l}\text { Neither Agree nor Disa- } \\
\text { gree }\end{array}$ & 2 & 5.4 & & & & \\
\hline & Somewhat Disagree & 2 & 5.4 & & & & \\
\hline & Total Agree & 33 & 89.2 & & & & \\
\hline & Total Disagree & 4 & 10.8 & & & & \\
\hline
\end{tabular}

The majority $(83.8 \%)$ of the app users agreed that using the app was an enjoyable experience, while there was a $64.9 \%$ net disagreement on the claim that the app is unnecessarily complex. This implies that the users believe that the app is by no means unnecessarily complex as they earlier claimed the app does everything they would expect it to do, as well as it works the way they would want it to.

$89.2 \%$ of the respondents agreed that the various functions in the app were well integrated; hence $91.9 \%$ agreed they would use the app frequently. Finally, the majority $(94.6 \%)$ of the respondents expressed their confidence in using the app; only $5.4 \%$ would not be confident using the app.

The next analysis addressing Research Question 2 was to investigate the use of artificial intelligence (AI) and machine learning (ML), and what the respondents thought about its use in the education sector. The results that were obtained showed that the majority of students think about Artificial Intelligence and Machine Learning 
in a positive way $(64.9 \%)$ while there was some disagreement $(35.1 \%)$ that the use of $\mathrm{AI}$ and ML can make learning more efficient, as shown in Table 5.

One of the reasons explained by many students was security concerns over using a network and privacy issues with fear of losing sensitive data, similar to studies conducted by Robinson [22]. Providing robust security and privacy for any web based application is challenging, however when using Cloud based Machine learning, these challenges become even more difficult to address [3] .

Table 5. Use of artificial intelligence (AI) and machine leaning (ML) in the higher education sector

\begin{tabular}{|c|c|c|c|}
\hline Question & Response & Frequency & Percent \\
\hline \multirow{2}{*}{$\begin{array}{l}\text { Do you believe the use of Artificial intel- } \\
\text { ligence and Machine learning can make } \\
\text { learning more efficient and effective }\end{array}$} & Strongly Agree or Agree & 24 & 64.9 \\
\hline & Strongly Disagree or Disagree & 13 & 35.1 \\
\hline
\end{tabular}

Based on the observations considered in this study, it was determined that the majority $(64.9 \%)$ of the respondents agree or strongly agree that the use of Artificial Intelligence and Machine Learning can make learning more efficient and effective, while $35.1 \%$ disagree or strongly disagree. In order to be able to make an inference from these results, an inferential test was conducted with details below:

\subsection{Hypothesis Testing}

Ho: There is no significant difference in the frequency of responses to the question of whether respondents believe the use of Artificial Intelligence and Machine Learning can make learning more efficient and effective.

Significance level $(\alpha): .05$

Table 6. Results of analysis

\begin{tabular}{|c|c|c|c|}
\hline Responses & Observed N & Expected N & Residual \\
\hline Strongly Agree or Agree & 24 & 18.5 & 5.5 \\
\hline Strongly Disagree or Disagree & 13 & 18.5 & -5.5 \\
\hline Total & 37 & & \\
\hline
\end{tabular}

Decision Rule: Reject the null hypothesis if the reported p-value is less than the level of significance (.05). Otherwise, do not reject.

Decision: Since the reported $\mathrm{p}$-value $=.243$ is greater than the level of significance (.05), the null hypothesis was not rejected.

This therefore led to more research, and a hypothesis test was performed. The pvalue was found to be .243 and the null hypothesis was not rejected. The conclusion obtained from the hypothesis test shows that there is no significant difference in the frequency of responses to the question of whether respondents believe the use of Artificial Intelligence and Machine Learning could make learning more efficient and effective. 
More students believe that AI and ML can make learning more effective and efficient. Students also provided reasons, as mobile applications in the future will become more efficient with the application of ML using the artificial neural network (ANN), which will provide an understanding of student learning behaviour and offer suggestions for future learning modules. They also suggested that learning will become more interactive and personal with the use of ML.

Table 7. Chi Square goodness of fit output table

\begin{tabular}{|c|c|}
\hline \multicolumn{2}{|c|}{ Test Statistics } \\
\hline & response \\
\hline Chi-Square & $.243^{\mathrm{a}}$ \\
\hline $\mathrm{df}$ & 1 \\
\hline Asymp. Sig. & .622 \\
\hline $\begin{array}{c}\text { a. } 0 \text { cells }(0.0 \%) \text { have expected frequencies less } \\
\text { than 5. The minimum expected cell frequency is } \\
18.5 \text {. }\end{array}$ \\
\hline
\end{tabular}

Research concludes that there is no significant difference in the frequency of responses to the question of whether respondents believe the use of Artificial Intelligence and Machine Learning can make learning more efficient and effective.

\section{Conclusion and research implication}

The main objectives of this study were to try and understand the main factors that affect the adoption of Cloud based learning systems in higher education, with the case study being based in Australia. The factors that could have affected the adoption were analysed, and the projected factors were mainly the attitude of the users towards the system and the application that was used in the learning process. The findings show that some of the factors that may have influenced the adoption are the Moodle application, which is the main software that is used to facilitate the learning process and the perception on artificial intelligence usage during the learning process. Some other factors that may have been contributors that were obtained from the study include trust, fulfilment of the expectations of the users in terms of performance, the ease of use of both the application and artificial intelligence, and the availability of the learning materials.

The study shows mobile learning as a learning process from both the perspective of the learner and that of the educator. It may be a problem for some people to have more access to learning materials than others, a factor which does not outweigh the benefit of having access to learning materials without making a full consideration on the hardware that has been used in the learning process. Therefore, the main advantage of Cloud computing is that it brings the learning process closer to the learners as opposed to the traditional forms of learning. The risks that may be seen from the learning process include the risk of losing control of the applications that may cause 
damage to personal information. The challenges that were identified that may be the main factor which hinders the adoption of the Cloud computing mobile learning are:

The mobile network condition: Since mobile learning largely considers the mobile network condition of the learner, some of the networks may be unsatisfactory in the delivering of a satisfactory learning experience to the learners.

Control of the learning applications: All the learning applications are done on the Internet, including the control of the applications and material, thus the user loses control of the applications.

Security and Privacy: The sensitive information of the learners may leak and this is one of the main reasons that may have influenced the low adoption of artificial intelligence in learning.

\section{$6 \quad$ Future research and limitation}

The current studies show that there is a limited scope of study on the factors that affect adoption especially in the Australian higher education sector. The research data was only collected from one Australian higher education institute. To generalise the findings in Australia, research should be sent to more institutions, and more students need to be targeted. There is also a need to conduct a more robust research to uncover some of these factors from multiple perspectives. It is also recommended that future study should include a mixed approach research that uses both qualitative and quantitative forms of study to uncover more factors.

\section{$7 \quad$ References}

[1] R. Sandu, Gide,E.,Karim,S., "An Analysis of SMEs Customer Behavior in Cloud-Based E-commerce Environment" Academic Journal of Science vol. 7, no. 2, pp. 281-292, 2017.

[2] Q.-K. Fu, and G.-J. Hwang, "Trends in mobile technology-supported collaborative learning: A systematic review of journal publications from 2007 to 2016," Computers \& Education, 2018. https://doi.org/10.1016/j.compedu.2018.01.004

[3] N. Beacham, and R. Duncan, "Development of a Secure Cloud Based Learning Environment for Inclusive Practice in Mainstream Education."

[4] K. Atchariyachanvanich, N. Siripujaka, and N. Jaiwong, "What makes university students use cloud-based e-learning?: case study of KMITL students." pp. 112-116.

[5] M. A. Bamiah, S. N. Brohi, and S. Chuprat, "Using virtual machine monitors to overcome the challenges of monitoring and managing virtualized cloud infrastructures." p. 83491M.

[6] Y.-T. Lin, M.-L. Wen, M. Jou, and D.-W. Wu, "A cloud-based learning environment for developing student reflection abilities," Computers in Human Behavior, vol. 32, pp. 244252, 2014. https://doi.org/10.1016/j.chb.2013.12.014

[7] H. Kimiloglu, M. Ozturan, and B. Kutlu, "Perceptions about and attitude toward the usage of e-learning in corporate training," Computers in Human Behavior, vol. 72, pp. 339-349, 2017. https://doi.org/10.1016/j.chb.2017.02.062

[8] X. Chen, J. Liu, J. Han, and H. Xu, "Primary exploration of mobile learning mode under a cloud computing environment." pp. 484-487. 
Paper-Analysis of the Main Factors Affecting the Adoption of Cloud based Interactive Mobile Learn...

[9] D. Burda, and F. Teuteberg, "The role of trust and risk perceptions in cloud archivingResults from an empirical study," The Journal of High Technology Management Research, vol. 25, no. 2, pp. 172-187, 2014. https://doi.org/10.1016/j.hitech.2014.07.008

[10] S. Ryan, B. Scott, H. Freeman, and D. Patel, The virtual university: The internet and resource-based learning: Routledge, 2013.

[11] R. sandu, "A Study to Analyse Economic Benefits of Cloud-Based Open Source Learning for Australian Higher Education Sector," ICSBE, pp. 9-12, 2017.

[12] M. G. Jaatun, G. Zhao, and C. Rong, Cloud Computing: First International Conference, CloudCom 2009, Beijing, China, December 1-4, 2009, Proceedings: Springer, 2009. https://doi.org/10.1007/978-3-642-10665-1

[13] K. Verma, S. Dubey, and M. Rizvi, "Support for cloud-based mobile learning," Blended Learning: Concepts, Methodologies, Tools, and Applications, pp. 843-865: IGI Global, 2017. https://doi.org/10.4018/978-1-5225-0783-3.ch043

[14] X. Wang, and B. Wong, "Bridging Knowledge Divides Utilizing Cloud Computing Learning Resources in Underfunded Schools: Investigating the Determinants," Journal of Educational Computing Research, pp. 0735633118759455, 2018. https://doi.org/10.1177/ 0735633118759455

[15] J. Li, "Study on the development of mobile learning promoted by cloud computing." pp. $1-4$.

[16] M. T. Baldassarre, D. Caivano, G. Dimauro, E. Gentile, and G. Visaggio, "Cloud Computing for Education: A Systematic Mapping Study,” IEEE Transactions on Education, 2018. https://doi.org/10.1109/TE.2018.2796558

[17] M. I. Jordan, and T. M. Mitchell, "Machine learning: Trends, perspectives, and prospects," Science, vol. 349, no. 6245, pp. 255-260, 2015. https://doi.org/10.1126/science. aaa8415

[18] O. Corrigan, "An Investigation Into Machine Learning Solutions Involving Time Series Across Different Problem Domains," Dublin City University, 2018.

[19] M. C. Gombolay, R. Jensen, and S.-H. Son, Machine Learning for Education: Learning to Teach, Massachusetts Inst of Teach, Lexington, United States, 2016.

[20] S. Ashtari, and A. Eydgahi, "Student Perceptions of Cloud Computing Effectiveness in Higher Education." pp. 184-191.

[21] M. B. Alotaibi, "Exploring users' attitudes and intentions toward the adoption of cloud computing in Saudi Arabia: an empirical investigation," Journal of Computer Science, vol. 10, no. 11, pp. 2315-2329, 2014. https://doi.org/10.3844/jcssp.2014.2315.2329

[22] A. Cook, M. Robinson, M. A. Ferrag, L. A. Maglaras, Y. He, K. Jones, and H. Janicke, "Internet of Cloud: Security and Privacy Issues," Cloud Computing for Optimization: Foundations, Applications, and Challenges, pp. 271-301: Springer, 2018. https://doi.org/10.1007/978-3-319-73676-1_11

[23] Kocakoyun, S. \& Bicen, H. (2017). Development and evaluation of educational android application. Cypriot Journal of Educational Sciences, 12(2), 58-68. https://doi.org/10.18844/cjes.v12i2.1938

[24] Soykan, E. \& Ozdamli F. (2016). The Impact of M-Learning Activities on the IT Success and M-Learning Capabilities of the Special Education Teacher Candidates. World Journal on Educational Technology: Current Issues, 8(3), 267-276. https://doi.org/10.18844/ wjet.v8i3.1019

[25] Karahoca, A., Karahoca, D. \& Buyuk, E. (2016). Conflict analysis for Turkish debates using text mining and text segmentation techniques. Global Journal of Computer Sciences: Theory and Research, 6(2), 19-25. https://doi.org/10.18844/gjcs.v6i2.1651 
Paper-Analysis of the Main Factors Affecting the Adoption of Cloud based Interactive Mobile Learn..

[26] Celik, O. \& Yavuz, F. (2018). The effect of using mobile applications on literal and contextual vocabulary instruction. International Journal of Learning and Teaching, 10(2), 126-136.

[27] Huang, Y. D., Feng, C. C., Peng, K. C., Chan, H. Y. \& Hu, C. C. (2017). The cloud classroom of the skeletal system. New Trends and Issues Proceedings on Humanities and Social Sciences. [Online]. 4(1), 285-290. https://doi.org/10.18844/prosoc.v4i1.2267

[28] Uzunboylu, H., Hursen, C., Ozuturk, G. \& Demirok, M. (2015). Determination of Turkish University Students' Attitudes for Mobile Integrated EFL Classrooms in North Cyprus and Scale Development: ELLMTAS. Journal of Universal Computer Science, 21(10), 12831296.

\section{Authors}

Nitirajsingh Sandu is with KENT Institute, Sydney, Australia.

Ergun Gide is with Central Queensland University, Sydney, Australia.

Article submitted 10 June 2018. Resubmitted 27 June 2018. Final acceptance 18 July 2018. Final version published as submitted by the authors. 